\title{
Implementasi Higiene Sanitasi pada RPH Kategori I sebagai Syarat Produksi Daging Sehat
}

\author{
Implementation of Hygiene Sanitation on $1^{\text {st }}$ Category Abbatoirs as Requisite of Healthy Meat Production \\ M. Fitri ${ }^{1 *}$, H. Nuraini ${ }^{2,3}$, R. Priyanto ${ }^{2}$, \& Y. C. Endrawati ${ }^{2,3}$ \\ ${ }^{1}$ Sekolah Pascasarjana, Departemen Ilmu Produksi dan Teknologi Peternakan, Fakultas Peternakan, \\ Institut Pertanian Bogor \\ ${ }^{2}$ Departemen Ilmu Produksi dan Teknologi Peternakan, Fakultas Peternakan, Institut Pertanian Bogor \\ ${ }^{3}$ Pusat Kajian Sains Halal, Institut Pertanian Bogor \\ Jalan Agatis, Kampus IPB Dramaga Bogor 16680, Indonesia \\ *Corresponding author: mona.fitri1279@gmail.com \\ (Received 23-07-2021; Revised 14-08-2021; Accepted 01-09-2021)
}

\begin{abstract}
Abbatoirs have to produce meat that complied requisite of safety, healthy, wholeness and halal. Animal origin product have to requisite basic safety product which implementated of hygine sanitation as production processed. The research aim was to evaluate implementation of hygine sanitation system on 1st categrory abbatoir at Bogor Regency to complied safety and quality assurance of product. Observations on the implementation of hygienic sanitation were carried out using an evaluation matrix of the suitability of physical requirements with the criterion parameter assessment method based on the Regulation of the Minister of Agriculture Number 13/2010. The best suitability value (NK) of 3 was obtained on the environmental hygiene indicator and the absence of the use of chemicals, while the other sanitation hygiene indicators were worth 2 (less appropriate). The results of testing on meat for the content of Salmonella sp. is negative and the Total Plate Count test is between $7.1 \times 10^{3}-5.2 \times 10^{4}$ cfu/g below the SNI threshold $\left(1.0 \times 10^{6} \mathrm{cfu} / \mathrm{g}\right)$. The test for $E$. coli in meat was above the threshold of suspected contamination from the water used. Validation of hygiene sanitation practices was carried out by means of Colliform swabs on knives, palms hand and clothing of officers. Colliform swab test of the officer's palm hand, which is $5.4 \times 10^{2} \mathrm{cfu} / \mathrm{g}$, shows a value above the allowable threshold. The results of the evaluation of the application of sanitation and hygiene in the abattoir are quite good but still need improvement. Priority improvements are the equipment of cleaning facilities, water quality testing and improvement of personal hygiene understanding.
\end{abstract}

Keywords: Abattoirs, Hygiene Sanitation, Microbial Contamination

\section{ABSTRAK}

Rumah pemotongan hewan harus menghasilkan daging yang memenuhi syarat aman, sehat, utuh dan halal. Produk asal hewan harus memenuhi persyaratan keamanan dasar produk yang menerapkan higiene sanitasi dalam proses produksinya. Penelitian ini bertujuan untuk mengevaluasi penerapan sistem higiene sanitasi pada RPH kategori 1 di Kabupaten Bogor untuk memenuhi jaminan keamanan dan mutu produk. Pengamatan terhadap pelaksanaan higiene sanitasi dilakukan dengan menggunakan matriks evaluasi kesesuaian persyaratan fisik dengan metode penilaian parameter kriteria berdasarkan Peraturan Menteri Pertanian Nomor 13/2010. Nilai kesesuaian (NK) terbaik 3 diperoleh pada indikator kebersihan lingkungan dan tidak adanya penggunaan bahan kimia, sedangkan indikator kebersihan sanitasi lainnya bernilai 2 (kurang sesuai). Hasil pengujian pada daging untuk kandungan Salmonella sp. negatif dan uji TPC antara 7.1 $\times 10^{3}-5.2 \times 10^{4} \mathrm{cfu} / \mathrm{g}$ di bawah ambang batas SNI (1.0 x 106 $\left.\mathrm{cfu} / \mathrm{g}\right)$. Pengujian E.coli pada daging berada di atas ambang batas diduga kontaminasi dari air yang digunakan. Validasi praktik higiene sanitasi dilakukan dengan cara swab Colliform pada pisau, telapak tangan dan pakaian petugas. Uji colliform swab telapak tangan petugas yaitu $5.4 \times 10^{2} \mathrm{cfu} / \mathrm{g}$ menunjukkan nilai di atas ambang batas yang diperbolehkan. Hasil evaluasi penerapan sanitasi dan higiene di RPH sudah cukup baik namun masih perlu perbaikan. Perbaikan yang diprioritaskan adalah peralatan fasilitas kebersihan, pengujian kualitas air dan peningkatan pemahaman personal higiene.

Kata kunci: kontaminasi mikroba, rumah pemotongan hewan, sanitasi higienis. 


\section{PENDAHULUAN}

Rumah Pemotongan Hewan adalah bangunan yang dirancang dengan desain tersendiri yang memenuhi persyaratan dan kriteria teknis serta sistem higienis sanitasiyang digunakan sebagai lokasi/area penyembelihan ternak supaya kebutuhan konsumen terpenuhi (BSN 1999). Hal tersebut berdasarkan penetapan Menteri Pertanian dalam Surat Keputusannya berkaitan dengan syarat-syarat Rumah Pemotongan Hewan-Ruminansia dan Unit Penghasil Daging yaitu lingkungan, fasilitas penunjang, konstruksi dan bentuk gedung serta fasilitas yang digunakan. Persyaratan dan implementasi sistem manajemen di RPH adalah suatu proses untuk mendapat produk asal hewan berupa daging yang aman dan halal.

Daging yang sehat dan aman adalah daging tidak terkontaminasi bakteri patogen yang menimbulkan penyakit serta residu pada saat dikonsumsi oleh masyarakat (Rohyati et al. 2017). Kunturo et al. (2012) menyatakan bahwa kontaminasi bakteri pada daging harus dapat diminimalkan supaya mendapatkan daging dengan kualitas yang baik. Penerapan sistem manajemen di RPH terutama sistem higienis sanitasimemiliki peranan penting karena sangat berpengaruh terhadap produk yang dihasilkan. Rochadi (2012) menyatakan bahwa sistem higienis sanitasidan kesrawan merupakan aspek yang harus diperhatikan dalam melakukan proses produksi di RPH. Perihal serupa juga diungkapkan oleh Deswita et al. (2018) bahwa cara menangani ternak dan karkas/daging di RPH yang tidak sesuai dengan SOP serta tidak memperhatikan sanitasi higienisnya maka daging yang dihasilkan tidak dijamin kualitas, keamanan, dan kehalalannya yang akan berdampak pada kesehatan konsumennya. Tujuan penelitian ini adalah untuk mengevaluasi penerapan sistem higieni sanitasi pada RPH Kategori I (yaitu RPH yang menghasilkan karkas hangat atau karkas tanpa pelayuan dingin) yang terletak di Kabupaten Bogor agar produk yang dihasilkan terjamin mutu dan keamanannya.

\section{MATERI DAN METODE}

\section{Materi}

Materi yang digunakan dalam penelitian ini adalah daging sapi bagian blade dan brisket, aquades, larutan buffered pepton water (BPW) 0,1\%, Plate Count Agar (PCA), Salmonella Polyvalent Flagellar, reagen kovac, Eschericia Coli Broth (ECB), Brilliant Green Lactose Bile Agar (BGLBB), Baird Parker Agar (BPA), Triple Sugar Agar (TSA).

Alat yang digunakan adalah alat tulis kantor, sarung tangan, cool box, plastik steril, kamera, almunium foil, stomacher, jarum inokulasi, tabung erlenmeyer, homogenizer, tabung reaksi, tabung pengencer, cawan petri, water bath, pipet volumetrik, tabung durham, inkubator, tabung serologi, timbangan digital, jarum okulasi, penghitung koloni, magnetic stirrer, bunsen, penangas air, botol media, lemari steril, gunting, pinset, autoclave, refrigerator, dan freezer.

\section{Metode}

Evaluasi higienis sanitasi di RPH dilakukan degan cara melakukan pengamatan selama tiga periode berdasarkan pada matriks kuisioner. Higienis sanitasipada RPH diamati berdasarkan Peraturan Menteri Pertanian Nomor 13 Tahun 2010. Pengambilan sampel daging dilakukan dengan cara random sampling terhadap ternak yang dipotong di RPH serta sampel swab pada pisau, telapak tangan dan pakaian petugas yang berkaitan langsung dengan proses produksi di RPH tersebut. Sampel daging dari potongan blade dan brisket diambil sebanyak $250 \mathrm{~g}$ untuk dianalisis total mikroba (TPC), Salmonella sp., dan E. coli. Sampel diambil pada saat setelah pemotongan yaitu pukul $21.00-01.00 \mathrm{WIB}$, kemudian diletakkan dalam wadah steril dan disimpan ke dalam cool box kemudian sampel dibawa ke laboratorium untuk dilakukan analisis.

\section{Analisis Data}

Higienis sanitasi merupakan salah satu katagori dari 17 jenis katagori persyaratan fisik di RPH. Evaluasi penerapan higienis sanitasi terdiri atas 11 indikator yaitu mulai dari kelengkapan fasilitas, lingkungan danjuga higienis personal. Nilai total bobot parameter $(\mathrm{B} p)$ higienis sanitasia dalah 16 poin dari 100 poin parameter persyaratan fisik. $\mathrm{B} p$ adalah bobot parameter kriteria standar sanitasi higienis, $\mathrm{S} p$ adalah skor kelas parameter pengamatan higienis sanitasidi RPH, dan NK adalah Nilai Kesesuaian RPH berdasarkan hasil pengamatan. Penilaian parameter disesuaikan dengan acuan kriteria kelas yang dikelompokkan ke dalam 3 (tiga) kelas yaitu sesuai (S) diberi skor kelas 3, kurang sesuai (KS) diberi skor kelas 2, dan tidak sesuai (TS) diberi skor kelas 1. Nilai parameter merupakan perkalian antara bobot dengan skor kelas. Nilai kesesuaian RPH merupakan penjumlahan nilai semua parameter yang dihitung dengan persamaan menurut Yusuf (2007):

$$
\mathrm{NK}=\sum_{p=1}^{n}(\mathrm{~B} p \times \mathrm{S} p)
$$

Data mikrobilogi yang diperoleh kemudian dianalisis dengan menentukan nilai rataan lalu membandingkannya dengan Standar Nasional Indonesia 7388:2009 tentang batas maksimum cemaran mikroba dalam pangan.

\section{HASIL DAN PEMBAHASAN}

\section{Profil RPH PT X}

Rumah Pemotongan Hewan PT X (RPH PT X) adalah RPH swasta yang pengelolaannya dilakukan dalam bentuk perseroan terbatas. Lokasi RPH berada di Kabupaten Bogor, yang di bangun pada tahun 2016 diatas tanah seluas $5000 \mathrm{~m}^{2}$. Usaha pemotongan ternak ini termasuk pada RPH kategori I, yaitu RPH tanpa fasilitas pelayuan sehingga yang dihasilkan adalah karkas hangat atau karkas segar.

Sapi yang dipotong di RPH PT X adalah sapi jenis Brahman cross yang berumur 2 tahun dengan bobot badan $340-500 \mathrm{~kg}$ dan jumlah pemotongan 8 ekor per hari, sedangkan pada saat menjelang hari besar Islam (puasa 
Ramadhan dan Idul Fitri) pemotongan meningkat menjadi 30 ekor per hari dengan jenis sapi yang sama. Sapi yang dipotong didatangkan dari Feedlot seperti PT Tanjung Unggul Mandiri, PT Widodo Makmur, PT Andini, PT Santori (JAPFA GROUP), serta PT Lembu Jantan Perkasa. Jumlah karyawan RPH ini adalah 13 orang dan 2 diantaranya merupakan juru sembelih halal yang sudah mempunyai sertifikat yang dikeluarkan oleh MUI.

\section{Evaluasi Implementasi Sistem Sanitasi Higiene}

Indikator higienis sanitasi yang diamati berdasarkan Peraturan Menteri Pertanian Nomor 13 Tahun 2010. Hasil pengamatan implementasi sistem higienis sanitasi pada RPH PT X dapat dilihat pada Tabel 1. Berdasarkan pengamatan (Tabel 1) dapat dilihat bahwa skor kelas parameter ( $\mathrm{S} b$ ) penerapan standar higienis sanitasidi RPH PT X terdapat dua point yang berada di skor kelas 3, yaitu indikator no 7 yaitu tidak menggunakan bahan kimia berbahaya untuk pangan dan indikator no 9 yaitu kebersihan lingkungan. Indikator yang lain berada di skor kelas 2 dan 1 .

Berdasarkan perolehan nilai tersebut maka dapat disimpulkan bahwa RPH ini belum sepenuhnya menerapkan sanitasi higiene baik pada fasilitas yang digunakan maupun higiene personalnya. Menurut Gaznur et al. (2017) faktor terjadinya kontaminasi mikroba pada RPH adalah sanitasi fasilitas/peralatan, higiene personal, kontak langsung dengan lantai, kontaminasi dari jeroan hijau yaitu isi dari rumen yang merupakan saluran pencernaan, air yang digunakan pada $\mathrm{RPH}$, serta tingginya mikroba dapat juga terjadi pada saat pengemasan, alat angkut, dan pendistrisbusian.

Penerapan standar higienis sanitasi yang kurang baik pada saat melaksanakan proses produksi akan berpengaruh terhadap tingkat pencemaran mikroba pada daging yang dihasilkan. Kuntoro et al. (2012) berpendapat bahwa tingginya tingkat cemaran mikroba ditentukan oleh aspek higienis sanitasi baik pada area produksi, fasilitas, petugas serta cara penanganan setelah pemotongan.

Hasil pengamatan di atas dapat disimpulkan bahwa potensi kontaminasi pada daging yang berasal dari RPH PT X dapat disebabkan oleh beberapa faktor diantaranya yaitu: belum adanya fasilitas khusus seperti peralatan untuk mencuci sepatu boots dan tangan pada saat melaksanakan proses produksi, peralatan yang akan dipakai tidak disterilkan terlebih dahulu; personal higienis belum diterapkan, yang terlihat belum tersedianya pakaian khusus yang sudah steril, dan sebagian besar petugas belum memakai boots, masker, hand gloves, serta hair net. Peralatan penunjang yang akan dipakai belum disterilkan, dan kurangnya pemahaman

Tabel 1. Matriks evaluasi hygiene sanitasi

\begin{tabular}{|c|c|c|c|c|c|c|}
\hline No & Indikator & $\mathrm{Bp}$ & Hasil Pengamatan & $\mathrm{Sp}$ & NK & Tindakan Koreksi \\
\hline 1 & $\begin{array}{l}\text { Persyaratan RPH dan UPD harus } \\
\text { dilengkapi dengan fasilitas higiene } \\
\text { sanitasi yang dapat memastikan } \\
\text { bahwa cara produksi karkas, dag- } \\
\text { ing, dan jeroan dapat diterapkan } \\
\text { dengan baik dan konsisten. }\end{array}$ & 1 & $\begin{array}{l}\text { Fasilitas higiene sanitasi belum } \\
\text { lengkap }\end{array}$ & 2 & 2 & $\begin{array}{l}\text { Mengupayakan melengkapi fasilitas } \\
\text { higiene-sanitasi }\end{array}$ \\
\hline 2 & $\begin{array}{l}\text { Fasilitas higiene sanitasi harus } \\
\text { mampu menjamin bahwa proses } \\
\text { produksi, peralatan, dan baju kerja } \\
\text { karyawan dapat diterapkan secara } \\
\text { efektif. }\end{array}$ & 1 & $\begin{array}{l}\text { Fasilitas higiene sanitasi belum } \\
\text { lengkap }\end{array}$ & 2 & 2 & $\begin{array}{l}\text { Mengupayakan penerapan } \\
\text { higiene-sanitasi secara efektif }\end{array}$ \\
\hline 3 & $\begin{array}{l}\text { Pada setiap pintu masuk } \\
\text { bangunan utama harus } \\
\text { memiliki fasilitas untuk mencuci } \\
\text { sepatu bot yang dilengkapi dengan } \\
\text { sikat sepatu, dan fasilitas untuk } \\
\text { mensucihamakan sepatu bot yang } \\
\text { dilengkapi desinfektan }\end{array}$ & 1 & Tidak tersedia & 1 & 1 & $\begin{array}{l}\text { Mengupayakan adanya fasilitas } \\
\text { untuk mencuci sepatu pada pintu } \\
\text { masuk bangunan utama }\end{array}$ \\
\hline 4 & $\begin{array}{l}\text { RPH dan atau UPD harus memiliki } \\
\text { fasilitas cuci tangan yang dileng- } \\
\text { kapi dengan air hangat, sabun, dan } \\
\text { desinfektan serta didisain tidak di- } \\
\text { operasikan menggunakan tangan } \\
\text { atau tidak kontak langsung dengan } \\
\text { telapak tangan. }\end{array}$ & 1 & Tidak tersedia & 1 & 1 & $\begin{array}{l}\text { Mengupayakan adanya fasilitas } \\
\text { untuk mencuci tangan }\end{array}$ \\
\hline 5 & $\begin{array}{l}\text { Fasilitas cuci tangan harus } \\
\text { dilengkapi dengan fasilitas } \\
\text { pengering tangan, apabila } \\
\text { menggunakan tissue maka harus } \\
\text { disediakan tempat sampah } \\
\text { bertutup dan tidak dioperasikan } \\
\text { dengan tangan. }\end{array}$ & 1 & Tidak tersedia & 1 & 1 & $\begin{array}{l}\text { Mengupayakan adanya fasilitas } \\
\text { pengering tangan seperti tissue serta } \\
\text { tempat sampah }\end{array}$ \\
\hline
\end{tabular}


Fitri et al.

Jurnal Ilmu Produksi dan Teknologi Hasil Peternakan 9 (3): 138-143

\begin{tabular}{|c|c|c|c|c|c|c|}
\hline No & Indikator & $\mathrm{Bp}$ & Hasil Pengamatan & $\mathrm{Sp}$ & NK & Tindakan Koreksi \\
\hline 6 & $\begin{array}{l}\text { Untuk mensucihamakan pisau dan } \\
\text { peralatan yang digunakan, harus } \\
\text { memiliki air bertemperatur tidak } \\
\text { kurang dari } 80{ }^{\circ} \mathrm{C} \text { yang memenuhi } \\
\text { persyaratan baku mutu air bersih } \\
\text { atau metode sterilisasi lain yang } \\
\text { efektif. }\end{array}$ & 1 & Tidak disterilkan & 1 & 1 & $\begin{array}{l}\text { Mengupayakan agar pisau yang akan } \\
\text { digunakan disterilkan terlebih } \\
\text { dahulu }\end{array}$ \\
\hline 7 & $\begin{array}{l}\text { Tidak menggunakan bahan kimia } \\
\text { berbahaya yang tidak diperboleh- } \\
\text { kan digunakan untuk pangan. }\end{array}$ & 2 & Tidak memakai bahan kimia & 3 & 6 & - \\
\hline 8 & $\begin{array}{l}\text { Setiap kali selesai proses } \\
\text { pemotongan dan produksi karkas, } \\
\text { daging, dan jeroan harus dilakukan } \\
\text { proses pembersihan dan desinfeksi } \\
\text { secara menyeluruh. }\end{array}$ & 2 & $\begin{array}{l}\text { Area produksi disiram dengan air } \\
\text { secara menyeluruh }\end{array}$ & 2 & 4 & $\begin{array}{l}\text { Mengupayakan agar pembersihan } \\
\text { area produksi menggunakan } \\
\text { desinfektan }\end{array}$ \\
\hline 9 & $\begin{array}{l}\text { Kebersihan lingkungan di sekitar } \\
\text { bangunan utama harus dipelihara } \\
\text { secara berkala, dengan cara: } \\
\text { menjaga kebersihan lingkungan } \\
\text { dari sampah, kotoran dan sisa } \\
\text { pakan; menjaga rumput dan } \\
\text { pepohonan sehingga tetap terawat; } \\
\text { menyediakan fasilitas tempat } \\
\text { pembuangan sampah sementara di } \\
\text { tempat-tempat tertentu. }\end{array}$ & 2 & $\begin{array}{l}\text { Kebersihan lingkungan dijaga } \\
\text { dengan baik }\end{array}$ & 3 & 6 & - \\
\hline 10 & Higiene personal harus diterapkan & 2 & $\begin{array}{l}\text { Masih terdapat petugas yang } \\
\text { mengabaikan kebersihan } \\
\text { pribadinya seperti mencuci } \\
\text { tangan }\end{array}$ & 1 & 2 & $\begin{array}{l}\text { Karyawan harus membersihkan } \\
\text { segala sesuatu yang berkaitan } \\
\text { langsung dengan proses produksi }\end{array}$ \\
\hline 11 & $\begin{array}{l}\text { Seluruh pekerja yang menangani } \\
\text { karkas, daging, dan/atau jeroan } \\
\text { harus menerapkan praktik higiene } \\
\text { antara lain: }\end{array}$ & 2 & $\begin{array}{l}\text { Petugas belum ada yang memakai } \\
\text { hair net dan pakaian kerja khusus. } \\
\text { Petugas juga masih merokok di } \\
\text { sekitar area produksi }\end{array}$ & 1 & 2 & $\begin{array}{l}\text { Karyawan harus menerapkan } \\
\text { higiene sanitasi ketika berlangsung- } \\
\text { nya proses produksi }\end{array}$ \\
\hline $\mathrm{a}$ & $\begin{array}{l}\text { Petugas yang menangani daging } \\
\text { harus dalam kondisi sehat, } \\
\text { terutama dari penyakit pernafasan } \\
\text { dan penyakit menular seperti TBC, } \\
\text { hepatitis A, tipus, dll; }\end{array}$ & & & & & \\
\hline $\mathrm{b}$ & $\begin{array}{l}\text { Petugas harus memakai alat } \\
\text { pelindung diri seperti: penutup } \\
\text { kepala (hair net), sepatu bot, dan } \\
\text { pakaian kerja; }\end{array}$ & & & & & \\
\hline $\mathrm{c}$ & $\begin{array}{l}\text { Melakukan cuci tangan secara rutin } \\
\text { ketika sebelum dan pasca } \\
\text { penanganan produk serta ketika } \\
\text { selesai dari kamar mandi/toilet; }\end{array}$ & & & & & \\
\hline $\mathrm{d}$ & $\begin{array}{l}\text { Tidak melakukan tindakan yang } \\
\text { dapat mengkontaminasi produk } \\
\text { (bensin, merokok, meludah, dll) di } \\
\text { dala bangunan utama rumah } \\
\text { potong. }\end{array}$ & & & & & \\
\hline & Total & 16 & & 18 & 30 & \\
\hline
\end{tabular}

$\mathrm{Bp}=$ bobot parameter $; \mathrm{Sp}=$ skor kelas parameter $; \mathrm{NK}=$ Nilai kesesuaian

petugas tentang pentingnya higienis sanitasi di lingkungan RPH terutama di area produksi.

Pengamatan Mikroba pada Daging

Hasil pengamatan terhadap mikroba daging sapi yang diperoleh dari RPH PT X dapat dilihat pada Tabel 2.
Kandungan Salmonella sp. dinyatakan negatif dan nilai TPC daging sampel juga berada dibawah nilai baku maksimum cemaran mikroba daging menurut SNI. Untuk kandungan E. coli ditemukan ada yang melebihi nilai baku maksimum yaitu pada sampel daging potongan brisket no. 1 dan 2 
Fitri et al.

Jurnal Ilmu Produksi dan Teknologi Hasil Peternakan 9 (3): 138-143

Tabel 2. Hasil uji mikroba pada daging

\begin{tabular}{|c|c|c|c|c|c|c|}
\hline \multirow[t]{3}{*}{ Sampel } & \multicolumn{6}{|c|}{ Jumlah Mikroba Pada Daging } \\
\hline & Blade & Brisket & Blade & Brisket & Blade & Brisket \\
\hline & \multicolumn{2}{|c|}{ TPC $(\mathrm{cfu} / \mathrm{g})$} & \multicolumn{2}{|c|}{ Salmonella sp. } & \multicolumn{2}{|c|}{ Escherichia coli (cfu/g) } \\
\hline Sapi 1 & $3.2 \times 10^{4}$ & $5.2 \times 10^{4}$ & Negatif & Negatif & $<1.0 \times 10^{1}$ & $1.5 \times 10^{1}$ \\
\hline Sapi 2 & $7.0 \times 10^{3}$ & $3.4 \times 10^{4}$ & Negatif & Negatif & $<1.0 \times 10^{4}$ & $1.0 \times 10^{4}$ \\
\hline Sapi 3 & $7.1 \times 10^{3}$ & $1.0 \times 10^{4}$ & Negatif & Negatif & $<1.0 \times 10^{1}$ & $<1.0 \times 10^{1}$ \\
\hline Sapi 4 & $1.3 \times 10^{4}$ & $9.0 \times 10^{3}$ & Negatif & Negatif & $<1.0 \times 10^{1}$ & $<1.0 \times 10^{1}$ \\
\hline SNI 7388:2009 & \multicolumn{2}{|c|}{$1.0 \times 10^{6}$} & \multicolumn{2}{|c|}{ Negatif } & \multicolumn{2}{|c|}{$1.0 \times 10^{1}$} \\
\hline
\end{tabular}

serta potongan blade no. 2 dengan jumlah di atas $1.0 \times 10^{1}$ $\mathrm{cfu} \mathrm{g}^{-1}$. Menurut Bahri et al. (2019) E. coli yang terdapat pada daging yang dihasilkan dari suatu RPH menunjukkan bahwa proses penanganan di RPH tersebut belum maksimal menerapkan sistem higiene sanitasi.

Aspek lain penyebab terjadi kontaminasi mikroba pada daging ialah sumber air yang digunakan saat proses pemotongan di RPH. Menurut Arieta et al. (2014) bahwa produk pangan asal hewan sangat rentan terkontaminasi dari area pemotongan seperti air, debu, tanah, dan udara. Cara penanganan yang baik untuk menghindari kontaminasi $E$. coli yaitu dengan memperhatikan serta menghindari potensi terjadinya kontaminasi seperti kontak langsung antara karkas/daging dengan lantai pada saat proses pengulitan (skinning). Sumber air yang digunakan untuk aktivitas produksi di RPH ini berasal dari sumur bor. Oleh karena itu sebaiknya dilakukan pengujian air secara periodik sehingga dapat diketahui kualitasnya.

Fikri et al. (2017) menyatakan bahwa untuk menghindari terjadinya kontaminasi silang melalui lantai sebaiknya pengulitan dilakukan dengan cara menggantung karkas terlebih dahulu serta mensterilkan fasilitas penunjang yang akan digunakan. Pendapat yang sama juga disampaikan oleh Tolistiawaty et al. (2015) bahwa pasca penyembelihan merupakan titik kritis tejadinya kontaminasi mikroba yaitu pada saat pengulitan, pengeluaran jeroan dan saat pengemasan.

Untuk memperoleh gambaran hasil proses pembersihan peralatan dan higiene karyawan, maka dilakukan uji Coliform dengan cara melakukan test swab pada mata pisau, pakaian dan telapak tangan karyawan. Pada Tabel 3 diperlihatkan hasil uji Coliform. Jumlah Coliform yang terdapat pada telapak tangan petugas adalah $5.4 \mathrm{x}$ $10^{2} \mathrm{cfu} / \mathrm{g}$. Tingginya jumlah Coliform pada telapak tangan petugas menunjukkan hasil yang kurang baik, kemungkinan karena petugas tidak mencuci tangan dengan menggunakan air yang mengalir.

Tabel 3. Hasil swab uji Colliform

\begin{tabular}{clc}
\hline No & \multicolumn{1}{c}{ Jenis Sampel } & Colliform $(\mathrm{cfu} / \mathrm{gr})$ \\
\hline 1 & Pisau & $<1.0 \times 10^{1}$ \\
2 & Telapak tangan petugas & $5.4 \times 10^{2}$ \\
3 & Pakaian petugas & $<1.0 \times 10^{1}$ \\
& SNI 7388:2009 & $1.0 \times 10^{2}$ \\
\hline
\end{tabular}

Kontaminasi silang dari personal karyawan dan air berpindah ke karkas begitu juga sebaliknya (Ollong et al. 2020). Higienis personal merupakan bagian dari terjadinya kontaminasi silang yang berpengaruh terhadap kualitas dan keamanan produk yang dihasilkan. Nurwantoro et al. (2006) menyatakan bahwa faktor utama terjadinya kontaminasi dan tingginya jumlah Coliform pada daging disebabkan oleh air $60 \%$ dan $40 \%$ dari petugas. Pelatihan higienis personal sangat diperlukan karena RPH harus menghasilkan produk yang sudah terjamin kualitas, keamanan, dan kehalalannya (Priyatno 1999). Sartono dan Deby (2011) menjelaskan bahwa selain higienis personal, fasilitas atau area yang digunakan untuk proses produksi sebaiknya disterilkan terlebih dahulu untuk mengurangi kontaminasi.

\section{KESIMPULAN}

Hasil evaluasi terhadap penerapan higiene sanitasi di RPH tempat penelitian sudah cukup baik namun masih memerlukan perbaikan. Beberapa prioritas perbaikan adalah perlengkapan fasilitas kebersihan, melakukan pengujian kualitas air dan peningkatan pemahaman higienis personal.

\section{UCAPAN TERIMAKASIH}

Penulis mengucapkan terimakasih kepada Badan Pengembangan Sumber Daya Manusia Aceh dan Dinas Peternakan Aceh yang telah memberi dukungan finansial dan kepada RPH PT X yang telah mengizinkan penulis untuk melaksanakan penelitian. 


\section{DAFTAR PUSTAKA}

Arieta, A. N., E. T. Pawenang, \& Mardiana. 2014. Hubungan higiene pedagang dan sanitasi dengan kontaminasi salmonella pada ayam potong. Unnes J. of Public Health. 3(4): 9-16.

BSN (Badan Standarisasi Nasional). 1999. SNI 01-61591999 Tentang Rumah Pemotongan Hewan. Jakarta (ID): BSN.

BSN (Badan Standarisasi Nasional). 2009. SNI 7388:2009 Tentang Batas Maksimum Cemaran Mikroba Dalam Pangan. Jakarta (ID): BSN.

Bahri, S., S. Rokhim, \& Y. S. Prasiska. 2019. Kontaminasi Bakteri Escherichia coli Pada Sampel Daging. JHSP. 3(1): 62-67. DOI: http/doi.org/10.29080/jhsp.v3i1.195.

Deswita, F. S., Razali, \& Ismail. 2018. Penilaian kelengkapan dan fasilitas sanitasi, prosedur pemotongan dan higiene pribadi di rumah pemotongan hewan Kota Banda Aceh. JIMVET E-ISSN. 2(1):188-195.

Fikri, F., I. S. Hamid, \& M. T. E. Purnama. 2017. Uji Organoleptis, pH, Uji Ebert dan Cemaran Bakteri pada Karkas yang Diisolasi dari Kios di Banyuwangi. J. Med.Vet. 1(1):23-27.

Gaznur, Z. M., H. Nuraini, \& Priyanto R. 2017. Evaluasi Penerapan Standar Sanitasi dan Hiegien di Rumah pemotongan hewan Kategori I. J. Vet. 18(1): 107-115. DOI: 10.19087/jveteriner.2017.18.1.107

Kementan (Kementrian Pertanian). 2010. Peraturan Menteri Pertanian Republik Indonesia Nomor 13/ Permentan/OT.140/1/2010 Tentang Persyaratan Rumah pemotongan hewan Ruminansia dan Unit Penanganan Daging (Meat Cutting Plant). Jakarta (ID): Kementrian Pertanian Republik Indonesia.

Kementan (Kementrian Pertanian). 2020. Peraturan Menteri Pertanian Republik Indonesia Nomor 11 Tahun 2020 Tentang Sertifikasi Nomor Kontrol Veteriner Unit Usaha Produk Hewan. Jakarta (ID): Kementrian Pertanian Republik Indonesia.

Kuntoro, B., R. Maheswari, \& H. Nuraini. 2012. Hubungan Penerapan Standard Sanitation Operational Procedure (SSOP) Terhadap Mutu Daging Ditinjau Dari Tingkat Cemaran Mikroba. J. Ilmiah Ilmu-Ilmu Peternakan Universitas Jambi XV(2):70-80.
MUI (Majelis Ulama Indonesia). 2009. Fatwa Majelis Ulama Indonesia Nomor 12 Tahun 2009 Tentang Standar Sertifikasi Pemotongan Halal. Jakarta (ID): Majelis Ulama Indonesia.

Nurwantoro, N., V. Bintoro, A. M. Legowo, \& A. Purnomoadi. 2012. Microbiological Properties of Beef in Various Meat Shop at Semarang Indonesia. JITAA. 37(2):97-102.

Ollong, A. R., J. A. Palulungan, \& R. Arizona. 2020. Analisis Jumlah Coliform dan Faecal coli (MPN) Pada Daging Sapid an Ayam di Kota manokwari. JIPVET. 10(2):113-118.

Priyatno, M. A. 1999. Mendirikan Tempat Pemotongan Ayam. Jakarta (ID): Penerbit Penebar Swadaya.

Rohyati, E., B. Ndoen, \& C. L. Penu. 2017. Kajian kelayakan operasional rumah pemotongan hewan (RPH) Oeba Pemerintah Kota Kupang Nusa Tenggara Timur dalam menghasilkan daging dengan kualitas asuh. J. Vet. 2(1):162-171.

Sartono, Deby. 2011. Studi Evaluatif Prosedur Penyembelihan Sapi di Rumah Pemotongan Hewan di Kota Pekanbaru. Riau (ID): Fakultas Pertanian dan Peternakan Universitas Islam Negeri Sultan Syarif Kasim.

Sugiyoto, S., K. Adhianto, \& V. Wanniatie. 2015. Kandungan Mikroba pada Daging Sapi dari Beberapa Pasar Tradisional di Bandar Lampung. JIPT. 3(2): 23333.

Tolistiawaty, I., J. Widjaja, R. Isnawati, \& L. T. Lobo. 2015. Gambaran rumah pemotongan hewan/tempat pemotongan hewan di Kabupaten Sigi Sulawesi Tengah. JVP. 9(2):45-52.

Yusuf, M. A. 2007. Metodologi Penelitian. Padang (ID): UNP Press. 